\title{
EKSPRESI INTERLEUKIN-1 (IL-1) B PADA ENDOMETRIOSIS, KARSINOMA ENDOMETRIOID DAN KARSINOMA SEROSUM OVARIUM
}

\section{THE EXPRESSION OF INTERLEUKIN-1 (IL-1) B ON OVARIAN ENDOMETRIOSIS, ENDOMETRIOID CARCINOMA AND SEROUS CARCINOMA}

\author{
Nadia Nur Lestari, Siti Amarwati, Udadi Sadhana, Dik Puspasari \\ Patologi Anatomi Fakultas Kedokteran Universitas Diponegoro / \\ RSUP Dr. Kariadi Semarang \\ Korespondensi:dr. Nadia Nur Lestari, Email: nadia.paundip@gmail.com
}

\begin{abstract}
ABSTRAK
Endometriosis ovarium memiliki resiko keganasan epithelial ovarium (resiko relatif 1.9 sampai 4.2). Karsinoma endometrioid adalah salah satu jenis keganasan yang paling sering berhubungan dengan endometriosis, sementara karsinoma serosum merupakan keganasan epitelial terbanyak pada ovarium.Serum sitokin pro-inflamasi interleukin-1 (IL-1) $\beta$ telah ditemukan berperan pada endometriosis dan karsinogenesis. Penelitian Keita, 2010, menemukan bahwa karsinoma endometrioid memiliki kadar IL-1 $\beta$ yang lebih tinggi secara bermakna dibandingkan jenis lainnya. Penelitian ini bertujua untuk mengetahui perbedaan ekspresi IL-1 $\beta$ pada jaringan endometriosis, karsinoma endometrioid dan karsinoma serosum ovarium. Desain penelitian ini adalah cross sectional design. Sampel adalah tiga puluh 33 blok parafin yang telah didiagnosis dan dire-evaluasi sebagai endometriosis (kelompok A), karsinoma endometrioid (kelompok B) dan karsinoma serosum ovarium

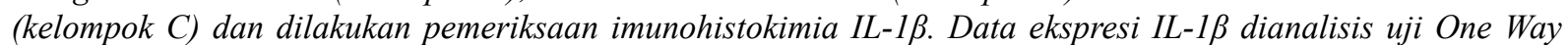
ANOVA, dilanjutkan dengan uji beda rerata Post Hoc. Hasil uji One Way ANOVA kelompok A, B dan C, p =0,037, menunjukkan adanya perbedaan bermakna. Uji beda rerata Post Hoc didapatkan kelompok $A$ vs kelompok $B$ dan $C(p=0,034$ dan $p=0,020)$ bermakna. Sedangkan kelompok $B$ vs kelompok $C(p=0,805)$ tidak bermakna. Dari penelitian ini dapat disimpulkan terdapatperbedaan yang bermakna ekspresi IL-1 $\beta$ antara endometriosis dengan karsinoma endometrioid dan karsinoma serosum ovarium, namun tidak terdapat perbedaan yang bermakna ekspresi IL-1 $\beta$ antara karsinoma endometrioid ovarium dan karsinoma serosum ovarium.
\end{abstract}

Kata kunci: Endometriosis, interleukin-1 $\beta$, karsinoma endometrioid, karsinoma serosum

\begin{abstract}
Ovarian endometriosis is associated with an increased risk of ovarian epithelial carcinoma (RR 1.9-4.2). Endometrioid carcinoma is one of the most common type of malignancy associated with endometriosis, while serous carcinoma is the most common ovarian cancer type. It has been reported that sera pro-inflammatory interleukin-1 (IL-1) $\beta$ evidently be involved in both endometriosis and ovarian carcinogenesis. Keita, 2010, demonstrated that IL-1 $\beta$ expression of endometrioid carcinoma is stronger than other EAOC. This study was aimed to observe the distinction of IL-1 $\beta$ tissue expression on endometriosis, endometrioid carcinoma and serous carcinoma ovarii. This study was a descriptive analytical study using cross-sectional design. Thirty three paraffin blocks of endometriosis (group A), endometrioid carcinoma (group B) and serous carcinoma ovarii (group C) that has already been diagnosed and reviewed, were stained with IL-1 $\beta$ antibody immunohistochemically. The data of $I L-1 \beta$ expression was analyzed with One Way ANOVA test, continued with Post Hoc test. There was a significantly difference of One Way ANOVA test $(p=0,037)$. Post Hoc test group $A$ vs group $B$ and $C$ were significant $(p=$ $0,034$ and $p=0,020)$, while group $B$ vs group $C$ was not significant $(p=0,805)$. There are some differences in $I L$ $1 \beta$ expression among ovarian endometriosis, endometrioid carcinoma, and serosum carcinoma, but there are no significantly difference between ovarian endometrioid carcinoma and serosum carcinoma.
\end{abstract}

Keywords: Endometriosis, interleukin-1 $\beta$, endometrioid carcinoma, serous carcinoma 


\section{PENDAHULUAN}

Endometriosis adalah kelainan ginekologi wanita, yang ditandai dengan adanya kelenjar dan stroma endometrium di luar uterus, terutama di ovarium dan peritoneum (Keita et al, 2011; Lawsonet al, 2007). Angka prevalensinya sulit ditetapkan dengan akurat, karena diagnosis definitif membutuhkan laparoskopi atau pembedahan (Agarwal \& Subramanian, 2010). Pada umumnya endometriosis ditemukan pada $10-20 \%$ wanita usia reproduktif, rata-rata $25-29$ tahun (Lawsonet al, 2007).

Jaringan endometriosis mengalami stres oksidasi, gangguan keseimbangan hormonal dan reaksi inflamasi kronik yang memicu pelepasan sitokin-sitokin pro-inflamasi, termasuk interleukin-1 (IL-1) $\beta$ (Keita et al, 2010).IL$1 \beta$ akan merangsang sel-sel stromal untuk mensintesa IL-6 dan vascular endothelial growth factor (VEGF) sehingga terjadi angiogenesis (Lebovic et al, 2000). Penelitian Hadisaputra, 2013, didapatkan VEGF berbanding lurus dengan derajat dan prognosis yang buruk pada endometriosis (Hadisaputra W, Prayudhana S, 2013). IL-1 $\beta$ pun merangsang cyclooxygenase 2 (COX2) memproduksi prostaglandin (PG) $\mathrm{E}_{2}$, merangsang gen steroidogenik dan menekan reseptor gonadothrophin releasing hormone (GnRH) (Nezhat et al, 2008). Semua kondisi tersebut, pada jangka waktu lama akan memicu proliferasi dan mempengaruhi kemampuan DNA untuk memperbaiki diri, sehingga ditemukan resiko keganasan epithelial ovarium meningkat sebanyak 3 kali lipat (resiko relatif 1.9 sampai 4.2) (Keita et al, 2011; Furuya, 2012; Robboy et al, 2009).

Keganasan epithelial ovarium yang sering berhubungan dengan endometriosis adalah karsinoma sel jernih, karsinoma endometrioid, karsinoma serosum dan karsinoma musinosum ovarium (Keita et al, 2010; Furuya, 2012). Karsinoma endometrioid adalah salah satu jenis yang paling sering berhubungan dengan endometriosis, sementara karsinoma serosum merupakan keganasan epitelial terbanyak pada ovarium (Robboy et al, 2009; Terada, 2012; Worley et al, 2013). Penelitian Keitaet al(2010), menemukan bahwa karsinoma endometrioid memiliki kadar IL-1 $\beta$ yang lebih tinggi secara bermakna dibandingkan jenis lainnya.

Berbagai penelitian telah dilakukan dengan sampel serum dan berbagai sitokin pro-inflamasi, namun penelitian IL-1 $\beta$ dengan sampel jaringan masih terbatas. Pada penelitian ini, ekspresi IL-1 $\beta$ diinterpretasikan pada sampel jaringan endometriosis, karsinoma endometrioid dan karsinoma serosum ovarium dengan pengecatan imunohistokima. Penelitian ini bertujuan untuk membuktikan adanya perbedaan ekspresi IL-1 $\beta$ pada endometriosis, karsinoma endometrioid dan karsinoma serosum ovarium.

\section{METODE}

Penelitian ini merupakan studi deskriptif dan analitik dengan desain belah lintang. Sampel terdiri atas tiga kelompok yang telah memenuhi kriteria inklusi dan eksklusi.Kelompok A adalah sebelas sampel endometriosis ovarium.Kelompok B adalah sebelas sampel karsinoma endometrioid ovarium.Kelompok $\mathrm{C}$ adalah sebelas sampel karsinoma serosum ovarium.Pemeriksaan imunohistokimia IL-1 $\beta$ dilakukan pada ketiga kelompok. Data ekspresi IL-1 $\beta$ dianalisis uji One Way ANOVA, dilanjutkan dengan uji beda rerata Post Hoc.

Penelitian ini telah mendapatkan persetujuan etik dari Komisi Etik Penelitian Kesehatan dan Kedokteran Universitas Diponegoro dan RSUP dr. Kariadi dengan nomor 35/EC/FK-RSDK/2015.

\section{HASIL DAN PEMBAHASAN}

Pada penelitian ini didapatkan 33 sampel yang diambil selama periode tahun 2012 - 2014, terdiri atas 11 kasus endometriosis ovarium, 11 kasus karsinoma endometrioid ovarium dan 11 kasus karsinoma serosum ovarium. Data yang kami ambil meliputi usia dan jenis kasus. 
Tabel 1. Karakteristik sampel berdasar kelompok usia

\begin{tabular}{lllllllll}
\hline \multirow{2}{*}{ Kelompok Kasus } & \multicolumn{7}{c}{ Kelompok Usia } \\
\cline { 2 - 8 } & $0-10$ & $11-20$ & $21-30$ & $31-40$ & $41-50$ & $51-60$ & $>60$ \\
\hline A & 0 & 1 & 1 & 4 & 3 & 2 & 0 \\
B & 0 & 0 & 0 & 3 & 6 & 0 & 2 \\
C & 0 & 0 & 0 & 2 & 3 & 6 & 0 \\
\hline
\end{tabular}

Berdasarkan tabel di atas, endometriosis ovarium terbanyak terjadi pada usia 31-40 tahun yaitu sebanyak 4 orang $(36,36 \%)$, sedangkan untuk karsinoma endometrioid ovarium usia 41-50 tahun sebanyak 6 orang $(54,54 \%)$ dan

karsinoma serosum ovarium usia 51-60 tahun juga sebanyak 6 orang $(54,54 \%)$. Dua $(18,18 \%)$ kasus endometriosis ovarium terjadi pada usia di atas 60 tahun. Gambaran histopatologi masing-masing kelompok dapat dilihat pada gambar 1.

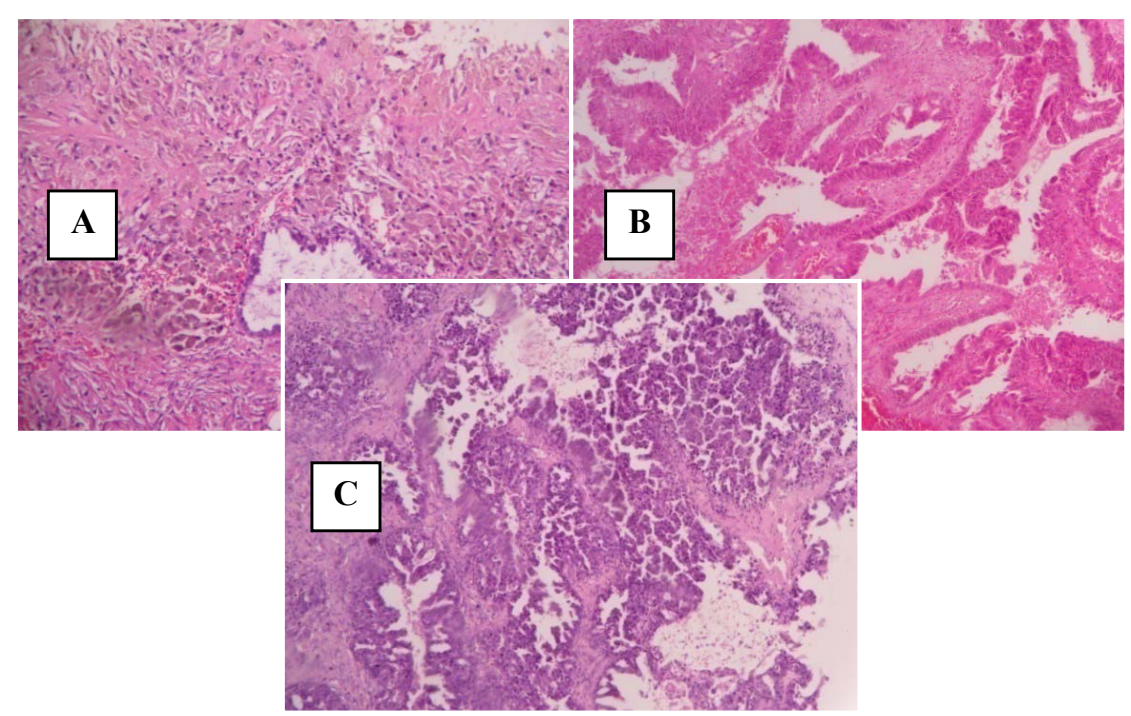

Gambar 1. Gambaran histopatologi (HE, 100x): A. Endometriosis ovarium. B. Karsinoma endometrioid ovarium. C. Karsinoma serosum ovarium.

Sampel yang sudah dipilih dan dire-evaluasi, kemudian dilakukan pemeriksaan imunohistokimia IL-1 $\beta$.Gambaran hasil pemeriksaan imunohistokimia IL-1 $\beta$ dengan intensitas ringan sampai kuat dapat dilihat pada gambar 2 .

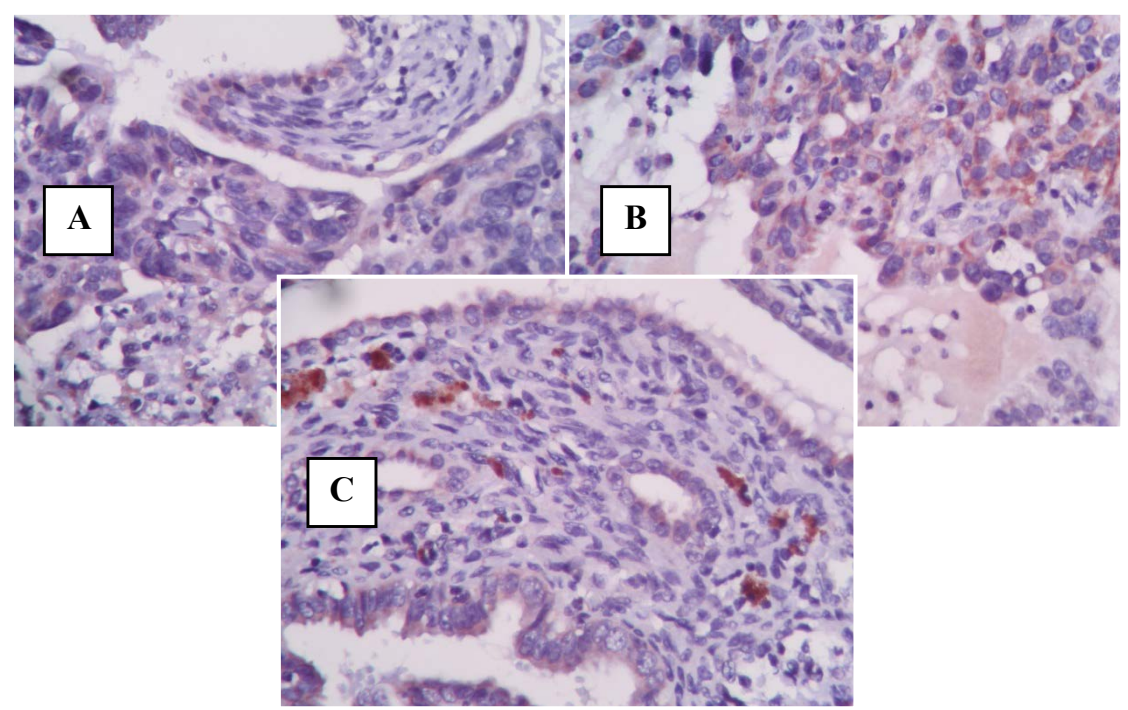

Gambar 2. Intensitas ekspresi IL-1 ß: A. Ringan (400x). B. Sedang (400x). C. Kuat (100x) 
Data hasil pulasan dibaca oleh dua orang ahli patologi menggunakan metode Allred. Hasil ekspresi IL-1 $\beta$ pada ketiga kelompok dapat dilihat pada tabel 2 .

Tabel 2.Data ekspresi IL-1 $\beta$

\begin{tabular}{ccc}
\hline Kelompok & Mean \pm SD & $\begin{array}{c}\text { Median } \\
(\mathbf{m i n}-\mathbf{m a k s})\end{array}$ \\
\hline $\mathrm{A}$ & $2,90 \pm 0,375$ & $2,9(2,3-3,5)$ \\
$\mathrm{B}$ & $2,42 \pm 0,733$ & $2,6(0,7-3,65)$ \\
$\mathrm{C}$ & $2,36 \pm 0,341$ & $2,4(1,85-3)$ \\
\hline
\end{tabular}

Berdasarkan tabel 2 di atas didapatkan rerata skor kelompok A 2,90 dengan standar deviasi $\pm 0,375$, kelompok B 2,42 dengan standar deviasi \pm 0,733 dan kelompok $\mathrm{C}$ 2,36 dengan standar deviasi $\pm 0,341$.

Data ekspresi IL-1 $\beta$ diuji normalitas dan homogenitasnya. Hasil uji normalitas terhadap variabel penelitian dengan menggunakan Shapiro-
Wilk Test didapatkan ketiganya mempunyai nilai $\mathrm{p}$ $>0,05$, dan dari uji homogenitas dengan Levene Statistic didapatkan nilai $\mathrm{p}>0,05$, sehingga dapat disimpulkan data berdistribusi normal dan homogen. Uji statisitik untuk data yang normal dan homogen dapat menggunakan uji One Way ANOVA.

Tabel 3. Uji normalitas dan homogenitas IL-1ß

\begin{tabular}{cccc}
\hline Kelompok & Mean \pm SD & Normalitas & Homogenitas \\
\hline A & $2,90 \pm 0,375$ & 0,538 & \\
B & $2,42 \pm 0,733$ & 0,200 & 0,218 \\
C & $2,36 \pm 0,341$ & 0,731 & \\
\hline
\end{tabular}

Berdasarkan uji normalitas, didapatkan sebaran dilanjutkan dengan uji hipotesis parametrik data yang normal, sehingga untuk melihat One Way ANOVA.Hasil uji hipotesis One Way adanya perbedaan antara ketiga kelompok dapat ANOVA dapat dilihat pada tabel 4.

Tabel 4. Uji beda rerata One Way ANOVA

\begin{tabular}{ccc}
\hline Kelompok & Mean \pm SD & p \\
\hline A & $2,90 \pm 0,375$ & \\
B & $2,42 \pm 0,733$ & $0,037^{*}$ \\
C & $2,36 \pm 0,341$ & \\
\hline
\end{tabular}

Keterangan : * Signifikan $\mathrm{p}<0,05$

Dari tabel hasil uji One Way ANOVA didapatkan nilai $\mathrm{p}=0,037$, karena $\mathrm{p}<0,05$ maka dapat disimpulkan terdapat perbedaan bermakna antar kelompok perlakuan. Untuk mengetahui perbedaan antar kelompok dilakukan uji lanjutan Post Hoc.Hasil uji lanjutan Post Hoc dapat dilihat pada tabel 5.

Tabel 5. Uji beda rerata Post Hoc

\begin{tabular}{ccc}
\hline Kelompok & B & C \\
\hline A & $0,034^{*}$ & $0,020^{*}$ \\
B & - & 0,805 \\
\hline
\end{tabular}

Keterangan : * Signifikan $\mathrm{p}<0,05$

Dari tabel uji beda rerata Post Hoc (kelompok B) dan karsinoma serosum ovarium didapatkan endometriosis ovarium (kelompok (kelompok $\mathrm{C}$ ) mempunyai nilai $\mathrm{p}<0,05$ atau A) terhadap karsinoma endometrioid ovarium signifikan. Sedangkan karsinoma endometrioid 
ovarium terhadap karsinoma serosum ovarium mempunyai nilai-nilai $\mathrm{p}>0,05$ atau tidak signifikan.

Sampel endometriosis pada penelitian iniditemukan paling banyak pada kelompok usia $31-40$ tahun (36,36\%). Sebanyak 18,18\% kasus terjadi pada usia di atas 60 tahun, kemungkinan berhubungan dengan pemakaian terapi sulih estrogen. Hal ini sesuai dengan penelitian Sourial tahun 2014 dan kepustakaan-kepustakaan yang ada (Lawson et al 2007; Agarwal \& Subramanian 2010; Robboy et al, 2009; Sourial Set al, 2014).

Seluruh sampel endometriosis yang diteliti dikirim dengan keterangan klinik neoplasma ovarium kistik.Massa berupa jaringan kista berisi bekuan darah berwarna coklat, yang dikenal sebagai kista coklat.Mikroskopik, dinding kista dilapisi epitel kuboid hingga kolumner selapis, sitoplasma eosinofilik di antara stroma retikuler sembab, hiperemik, disertai perdarahan, bersebukan sel-sel radang termasuk hemosiderinladen macrophages yang menandakan adanya perdarahan lama.Sampel endometriosis di Laboratorium PA RSDK cukup banyak jumlahnya, namun sedikit sekali sampel yang masih utuh dilapisi epitel. Sebagian besar epitel hilang karena reaksi oksidasi maupun prosesing sehingga menegakkan diagnosis pasti lebih baik didukung pemeriksaan imunohistokimia CD10 yang akan memastikan bahwa stroma jaringan tersebut adalah stroma endometrium (Agarwal \& Subramanian 2010; Lin \& Pitchard 2015).Pada penelitian ini tidak dilakukan pemeriksaan imunohistokimia CD10, karena itu pemilihan sampel cukup ketat pada jaringan endometriosis yang masih dilapisi epitel endometrium dan kami dapatkan 11 sampel selama periode tahun 2012-2014. Kami tetapkan periode ini atas pertimbangan kondisi pengarsipan, blok dan slide HE yang ada.

Pada endometriosis yang lama, terdapat resiko terjadinya transformasi keganasan baik yang berasal dari epitel maupun stroma. Resiko keganasan epitel ovarium meningkat sebanyak 3 kali lipat (resiko relatif 1.9 sampai 4.2) (Keita et al, 2010; Munksgaard \& Blaakaer 2011; Furuya, 2012; Robboy et al, 2009).Karsinoma endometrioid, karsinoma sel jernih, karsinoma serosum, dan karsinoma musinosum, termasuk di dalamnya (Furuya, 2012; Robboy et al, 2009;
Terada T, 2012; Worley et al, 2013; Macciò, and Madeddu, C 2012;Koshiyama et al, 2014; Gerard et al, 2004).Bukan hal mudah menegakkan diagnosis EAOC.Sel-sel ganas mampu merusak dan merubah stroma sekitarnya, termasuk jaringan endometriosis di mana dia berasal (Furuya, 2012). Penelitian di Jepang tahun 2012, selama 15 tahun, hanya ditemukan 15 kasus karsinoma endometrioid ovarium dan hanya $40 \%$ di antaranya yang disertai lesi endometriosis (Terada, 2012).Pada penelitian ini, selama periode 2012 - 2014 ditemukan 11 sampel karsinoma endometrioid ovarium, tanpa disertai lesi endometriosis, begitu pula pada 11 sampel karsinoma serosum ovarium.

Berbeda dengan jaringan endometrium, jaringan endometriosis memiliki enzim aromatase, tetapi tidak memiliki enzim17 $\beta$-HSD-2.Hal ini menyebabkan tingginya kadar estradiol. Hormon ini akan memicu COX-2, yang menyebabkan peningkatan sintesa PGE2. Kadar PGE2 yang tinggi akan merangsang aktivitas aromatase sehingga terjadi positive feedback loop pembentukan estradiol (Munksgaard \& Blaakaer 2011; Sourial et al, 2014).

Menstruasi retrograde dan perdarahan berulang pada jaringan endometriosis fungsional menyebabkan akumulasi berlebih molekul hem dan ion $\mathrm{Fe}^{++}$bebas yang persisten (Munksgaard PS, Blaakaer J, 2011; Koshiyama et al, 2014).Hal ini menyebabkan sel-sel epitel terpapar stress oksidatif (Reactive Oxigen Species (ROS), hipoksia, kerusakan DNA dan inflamasi kronik. Beberapa penelitian, termasuk yang dilakukan oleh Maccio dkk, menunjukkan adanya korelasi antara derajat inflamasi kronik, stadium lanjut dan hasil akhir yang buruk pada pasien EAOC (Munksgaard PS, Blaakaer J, 2011; Nezhat et al, 2008; Worley et al, 2013; Macciò, and Madeddu, 2012).

Sel-sel radang yang teraktivasi akan melepaskan mediator inflamasi, beberapa sitokin (IL-1, TNF $\alpha$, IL-6, IL-8) dan growth factor(Munksgaard PS, Blaakaer J, 2011; Furuya, 2012; Lin \& Pitchard 2015). Sitokin IL-1 $\beta$ merangsang sel-sel stromal endometriosis untuk mensintesa VEGF dan IL-6, yang menyebabkan terjadinya angiogenesis (Lebovic et al, 2000; Hadisaputra \& Prayudhana, 2013; Gerard et al, 2004; White et al, 2012).Selain itu IL-1 $\beta$ juga mampu menghambat apoptosis dengan cara 
meningkatkan produksi NO, meningkatkan akumulasi laktat intrasel, meningkatkan konsumsi dan transpor glukosa (Gerard et al, 2004).

Kombinasi IL-1 $\beta$ dan kadar estradiol yang tinggi menyebabkan peningkatan ekspresi COX2 sehingga sintesa PGE2 meningkat. PGE2 juga menimbulkan angiogenesis dan proliferasi, yang merupakan petanda pertumbuhan tumor (Munksgaard \& Blaakae, 2011; Worley et al, 2013; Sourial et al, 2014; Gerard et al, 2004).

Pada penelitian ini, pemeriksaan imunohistokimia IL-1 $\beta$ dilakukan pada 11 sampel endometriosis, 11 sampel karsinoma endometrioid dan 11 sampel karsinoma serosum ovarium. Hanya dua jenis keganasan yang diteliti dengan pertimbangan bahwa karsinoma endometrioid adalah salah satu jenis yang paling sering berhubungan dengan endometriosis, sementara karsinoma serosum merupakan keganasan epitelial terbanyak pada ovarium (Robboy et al, 2009; Terada T, 2012; Worley et al, 2013).Penelitian White KL tahun 2014 didapatkan IL-1 $\beta$ berhubungan dengan keganasan epithelial ovarium, kecuali karsinoma serosum (White et al, 2012). Dan penelitian Keita tahun 2010 menunjukkan bahwa pada pemeriksaan PCR dan ELISA, didapatkan peningkatan ekspresi IL-1 $\beta$ pada karsinoma endometrioid ovarium yang cukup signifikan dibandingkan jenis lainnya (Keita et al, 2010).

Pemeriksaan imunohistokimia, ekspresi IL-1 $\beta$ tercat berwarna coklat pada sitoplasma sel epitel, sel-sel radang terutama hemosiderin-laden macrophages dan stroma ekstraseluler (Dinarello CA, 1988; Gerard et al, 2004).Data ekspresi IL-1 $\beta$ dinilai dengan metode Allred oleh dua orang ahli patologi, dan didapatkan intensitas sedang $(2,90$ $\pm 0,375)$ pada sampel endometriosis ovarium, sementara sampel karsinoma endometrioid dan karsinoma serosum ovarium menunjukkan ekspresi IL-1 $\beta$ dengan intensitas ringan $((2,42 \pm$ $0,733)$ dan $(2,36 \pm 0,341))$.

Data ekspresi IL-1 $\beta$ diuji normalitas dan homogenitasnya. Hasil uji normalitas terhadap variabel penelitian dengan menggunakan ShapiroWilk Test didapatkan ketiganya mempunyai nilai $\mathrm{p}$ $>0,05$, dan dari uji homogenitas dengan Levene Statistic didapatkan nilai $\mathrm{p}>0,05$, sehingga dapat disimpulkan data berdistribusi normal dan homogen. Uji statisitik untuk data yang normal dan homogen dapat menggunakan uji One Way ANOVA.
Sampel endometriosis menunjukkan ekspresi IL-1 $\beta$ yang berbeda secara bermakna dengan karsinoma endometrioid, di mana ekspresi IL-1 $\beta$ lebih kuat pada sampel endometriosis dibandingkan sampel dengan karsinoma endometrioid. Hal ini berbeda dengan hasil penelitian Hadisaputro tahun 2013 dan Maccio tahun 2012 yang secara tidak langsung menunjukkan bahwa IL-1 $\beta$, melalui VEGF akan meningkat dan memberi korelasi positif dengan stadium lanjut dan prognosis yang buruk pada endometriosis, dalam hal ini transformasi keganasan (Hadisaputra \& Prayudhana, 2013; Macciò \& Madeddu, 2012).

Sampel endometriosis menunjukkan ekspresi IL-1 $\beta$ yang berbeda secara bermakna dengan karsinoma serosum, di mana ekspresi IL-1 $\beta$ lebih kuat pada sampel endometriosis dibandingkan sampel dengan karsinoma serosum. Hal ini sesuai dengan penelitian White KL tahun 2012 yang menunjukkan bahwa jalur inflamasi yang berperan penting pada transformasi keganasan karsinoma serosum bukanlah jalur IL$1 \beta$ (White et al, 2012).

Penelitian ini didapatkan IL-1 $\beta$ yang terekspresi pada sampel karsinoma endometrioid dan sampel karsinoma serosum ovarium tidak berbeda secara bermakna. Hal ini berbeda dengan hasil penelitian White KL tahun2012 dan Keita tahun 2010 yang menunjukkan ekspresi IL$1 \beta$ lebih tinggi pada karsinoma endometrioid dibandingkan dengan karsinoma serosum.

Perbedaan-perbedaan di atas dapat menjelaskan bahwa masih banyak faktor yang harus diteliti pada transformasi keganasan endometriosis, dengan periode penelitian yang lebih panjang, sampel yang lebih besar, kriteria inklusi dan eksklusi yang lebih cermat juga metode pemeriksaan lain agar transformasi keganasan pada endometriosis ini dapat segera dideteksi.

\section{KESIMPULAN}

Hasil penelitian mendapatkan kesimpulan sebagai berikut; 1) terdapat perbedaan yang bermakna ekspresi IL-1 $\beta$ antara endometriosis dan karsinoma endometrioid ovarium $(\mathrm{p}=$ $0,034)$, dengan ekspresi IL-1 $\beta$ lebih tinggi pada endometriosis daripada karsinoma endometrioid ovarium, 2) terdapat perbedaan yang bermakna 
ekspresi IL-1 $\beta$ antara endometriosis dan karsinoma serosum ovarium $(\mathrm{p}=0,020)$, dengan ekspresi IL-1 $\beta$ lebih tinggi pada endometriosis daripada karsinoma serosum ovarium, dan 3) tidak terdapat perbedaan yang bermakna ekspresi IL- $1 \beta$ antara karsinoma endometrioid dan karsinoma serosum ovarium $(\mathrm{p}=0,805)$.

\section{DAFTAR PUSTAKA}

Agarwal N, Subramanian A. 2010. Endometriosis - morphology, clincal presentations and molecular pathology. J Lab Physicians; 2(1):1-9.

Dinarello CA, 1988. Biology of interleukin-1. FASEB $J ; 2: 108-15$

Furuya MS, 2012.Ovarian cancer stroma: Pathophysiology and the roles in cancer development. Cancers; 4:701-24

Gerard N, Caillaud M, Martoriati A, Goudet G, Lalmanach AC. 2004. The interleukin-1 system and female reproduction. JEndocrinol; 180:203-12.

Hadisaputra W, Prayudhana S. 2013. Serum biomarker profiles of interleukin-6, tumor necrosis factor-alpha, matrixmetalloproteinase-2, and vascular endothelial growth factor in endometriosis staging. Med J indones; 22(2):76-82

Keita M, Bessette P, Pelmus M, Ainmelk Y, Aris A. 2010. Expression of interleukin-1 (IL1) ligand system in the most common endometriosis associated ovarian cancer subtypes. J ovarian res; 3(3):1-8.

Koshiyama M, Matsumura N, Konishi I. 2014. Recent concept of ovarian carcinogenesis: type I and type II. BioMed Res Int;1-11

Lawson C, Al-akoum M, Maheux R, Akoum A. 2007. Increased expression of interleukin-1 receptor type 1 in active endometriotic lesion.Reproduction; 133:265-74

Lebovic DI, Bentzien F, Chao VA, Garrett En, Meng YG, Taylor RN. 2000. Induction of an angiogenic phenotype in endometriotic stromal cell cultures by interleukin-1beta. Mol Hum Reprod; 6(3):269-75
Lin F, Pitchard J. 2015.Unknown primary/ undifferentiated neoplasm.In Handbook of practical immunohistochemistry. New York: Springer; 131.

Macciò A, Madeddu C., 2012. Inflammation and Ovarian Cancer, Ovarian Cancer - Basic Science Perspective, Dr. Samir Farghaly (Ed.), InTech, Available from:http://www. intechopen.com/books/ovarian-cancerbasic-science-perspective/inflammationand-ovarian-cancer, Italy. 2012.17-50

MunksgaardPS \& BlaakaerJ.2011. Theassociation between endometriosis and ovarian cancer: A review of histologycal, genetic and molecular alterations. Gynecol Oncol;1-6. doi:10.1016/j.ygyno.2011.10.001

Nezhat F, Datta S, Hanson V, Pejovic T, Nezhat C. 2008. The relationship between endometriosis and ovarian malignancy: a review. Fertil Steril; 90:1559-70.

Robboy SJ, Haney A \& Russell P. 2009. Endometriosis. In SJ Robboy, GL Mutter, J Prat, RC Bentley, P Russell, MC Anderson editors. Pathology of the Female Reproductive Tract. London: Churchill livingstone elsevier;.pp.515-41

Sourial S, Tempest N, Hapangama DK. 2014.Theories of the pathogenesis of endometriosis.Int $J$ Reprod Med :1-10. Cited: 15 Oktober 2014

Terada T, 2012. Endometrioid adenocarcinoma of the ovary arising in atypical endometriosis. Int J clin Exp pathol; 5(9):924-7.

White KL, Schildkraut JM, Palmieri RT, 2012. Ovarian cancer risk associated with inherited inflammation-related variants. AmAssocCancerResJ:1-20. Cited: 27 Agustus 2014

Worley MJ, Welch WR, Berkowitz RS, Ng SW.,2013.Endometriosis-associated ovarian cancer: A review of pathogenesis. Int. J. Mol.Sci; 5367-79. 